Article

\title{
Indigenous Relationality: Women, Kinship and the Law
}

\author{
Patricia Dudgeon ${ }^{1, *}$ and Abigail Bray ${ }^{2}$ \\ 1 School of Indigenous Studies, The University of Western Australia, Crawley WA 6009, Australia \\ 2 Independent Researcher, London N7 8AN, UK; abigailbray101@icloud.com \\ * Correspondence: pat.dudgeon@uwa.edu.au; Tel.: +61-86-488-3428
}

Received: 19 February 2019; Accepted: 23 April 2019; Published: 26 April 2019

check for updates

\begin{abstract}
Strong female governance has always been central to one of the world's oldest existing culturally diverse, harmonious, sustainable, and democratic societies. Aboriginal and Torres Strait Islander women's governance of a country twice the size of Europe is based on complex laws which regulate relationships to country, family, community, culture and spirituality. These laws are passed down through generations and describe kinship systems which encompass sophisticated relations to the more-than-human. This article explores Indigenous kinship as an expression of relationality, culturally specific and complex Indigenous knowledge systems which are founded on a connection to the land. Although Indigenous Australian women's kinships have been disrupted through dispossession from the lands they belong to, the forced removal of their children across generations, and the destruction of their culture, community and kinship networks, the survival of Indigenous women's knowledge systems have supported the restoration of Indigenous relationality. The strengthening of Indigenous women's kinship is explored as a source of social and emotional wellbeing and an emerging politics of environmental reproductive justice.
\end{abstract}

Keywords: Aboriginal and Torres Strait Islander kinship; kincentric ecology; relationality; Indigenous governance; social and emotional wellbeing; self-determination; Indigenous knowledge systems

Inter-connected axiologies, ontologies and epistemologies of kinship are at the center of the complex knowledge systems of Aboriginal and Torres Strait Islander women, knowledge systems which supported the governance of one of the earth's oldest harmonious, culturally diverse democracies. Although the invasion and colonization of their land disrupted the practice of women's knowledge systems, undermined women's cultural authority, and subjected them to catastrophic human rights abuses, Aboriginal and Torres Strait Islander women continue to resist the colonial erasure of their kinship laws and their culture. While colonization continues to disrupt women's harmonious kinship relations, a strong women's culture continues to protect those relations. In her historic 'Because of Her, We Can' speech at the 2018 National Aboriginal and Torres Strait Islander Women's Conference, the first woman Aboriginal and Torres Strait Islander Social Justice Commissioner, June Oscar AO, talks of this women's knowledge and resistance.

'She'-our founding mothers, the first women who have walked this land for millennia, and have birthed and nurtured centuries of our people into existence.

'She', who has carried our stories and knowledge, so we hold in our hands today our societal values of intergenerational learning, care and responsibility for our land, our families and communities. Embedded within these values are intrinsic lessons of our complex kinship structures and cultural practices. These teach us of collective leadership, collaborative and inclusive decision-making, negotiation and cooperation, the reciprocal sharing of resources, life-long education and the foundational understanding that an individual's health and 
wellbeing is intimately attached to the health of our country, our surrounding environments, and our families and communities. (Oscar 2018).

This paper acknowledges that the process of colonization disrupted women's protective kinship relations through the forced removal of their children, genocidal forms of assimilation, sexual assault and exploitation, dispossession from community and Country and the subsequent destruction of women's Laws, and that like other colonized Indigenous women, Aboriginal and Torres Strait Islander women endure the traumatic impacts of generations of reproductive oppression. However, the continuation of strong and dynamic kinship relations between Indigenous women, their families, communities and their land has also been the source of growing forms of resistance against cultural destruction.

The restoration of kinship connections supports the holistic strengthening of women's wellbeing. Indigenous understanding of health and wellbeing are relational, cultural and holistic and a kinship relationship to land underpins wellbeing. 'Our bodies and the land are connected. Our health and well-being are tied together' (Watson 2008, p. 99). Various studies have found that building strong kinship systems improves the maternal health of Indigenous women (Dietsche et al. 2011). There is now a growing body of evidence that restoring kinship with the land is vital to the empowerment of SEWB (Burgess et al. 2009; Burgess et al. 2008; Biddle 2011; Biddle and Swee 2012). Kinship with Country can be understood as a relationship with mother, or as the Noongar people call her "'Boodjar" or "nourishing terrain," a nurturing, creative, fertile place' (Wooltorton et al. 2017, p. 1). Healing kinship with the land is often taught by those who are working directly as guardians of the land, such as the Indigenous Martu women rangers who teach cultural knowledge of edible plants: 'each plant has its own songs, places, stories and laws, and has special techniques, tools, knowledge and skills to prepare them' (Country Needs People: Protecting Nature, Transforming Lives 2018, p. 88). Many traditional women-led Indigenous health programs for women and girls take pregnant women onto Country so they can be guided into strengthening kinship with the land, especially in sacred women's sites where the intelligence of the Law is protected (Carter et al. 1987; Lowell et al. 2015). Moreover, as custodians of the land now called Australia, Indigenous women have been at the forefront of movements to restore healing connections to land which include asserting the right to be custodians of the land.

In what follows, this article offers an introduction to recent research on Indigenous kinship systems, explores culturally specific articulations of Aboriginal and Torres Strait Islander women's kinship laws, and, finally, discusses Birthing on Country, a cultural practice which strengthens women's social and emotional wellbeing (SEWB). A holistic strengths-based concept of health which encompasses seven inter-related domains of wellbeing-Country, spirituality, culture, community, family and kinship, mind and emotions, and body-SEWB is a dynamic and evolving Indigenous discourse which has become increasingly important to comprehensive and targeted primary health care policy and Indigenous social sciences (Dudgeon and Walker 2015; Dudgeon et al. 2017). The dominant social and cultural determinant of SEWB is colonization which subjected Aboriginal and Torres Strait Islander women to forms of reproductive oppression, such as the forced removal of their children across generations, dispossession from homelands, and the suppression of women's cultural practices surrounding pregnancy, birth and child-rearing. Restoring Aboriginal and Torres Strait Islander women's SEWB by strengthening kinship relations through the Birthing on Country models of care is a form of environmental reproductive justice (Hoover 2018; Dudgeon and Bray 2019) which supports the flourishing of culture through custodial kinship with the land. For example, women have mobilized against the destruction of sacred 800-year-old birthing trees on Djap Wurrung country (in Victoria, Australia), where over 50 generations of Indigenous people have been born (Hayman-Reber 2018).

\section{Indigenous Kinship Systems}

Indigenous kinship systems are recognized as fundamentally different from western genealogical systems, encompassing complex relationships with place, with the land (earth, waterways, sky), and the more-than-human (animal, plant and spirt) which express culturally specific gendered obligations 
and laws, or forms of Indigenous spiritual governance. These sophisticated relationships weave the 'kincentric' (Salmon 2000) fabric of Indigenous culture, 'shaping their stewardship ethics and practices' (Reo and Ogden 2018, p. 1450). Central to Indigenous understanding of kinship, and to Indigenous knowledge systems in general, is the concept of 'relationality' which is expressed through 'culturally specific and gendered axiologies, ontologies, and epistemologies that are connected to the earth' (Moreton-Robinson 2017, p. 71, emphasis added) and 'embedded in Indigenous knowledge systems (Watson 2016, p. 14). The philosophical complexity of Indigenous knowledge systems has resisted assimilation into western epistemologies which tends to be dominated by hierarchical dichotomies, predicated on a division between nature and culture, and governed by a logic of linearity and separation. Understanding Indigenous 'relationality' requires attention to the process of connection-' $[\mathrm{t}]$ he way to understand anything is in its relationships' (Rose et al. 2003, p. 61)—a process which is often described as spiritual, a sacred life force, the source of the Dreaming or Aboriginal spiritual governance. This life force has numerous names across the different Indigenous cultures in Australia: Tjukurpa belongs to the Anangu people, Altjiringa belongs to the Aranada people, the Djugar belongs to the Altjidja people, the Bugari belongs to the Karadjeri people, the Unggud is connected to the Ungarinyin people, and the Wiradjeri call this force the Maratal (Elkin 1993, p. 4). Another term for this kincentric Indigenous knowledge system is 'Raw Law' (Watson 2016): 'the law is filled with the spirit of creation' (Watson 1998, p. 1). The law comes from the land, is the land. As Elder Bill Neidjie puts it: 'Listen carefully, careful and this spirit e come in your feeling and you Will feel it ... anyone that, I feel it ... my body same as you' (Neijie 1989, p. 182). For many Indigenous cultures, this law is a worldview, an ethics, which is governed by responsibility and reciprocity towards human and more-than-human kin (Powell and Curley 2008; Wilson and Inkster 2018). As a Ngiyampaa man, Phil Sullivan, states: 'Connection is a form of knowledge. You have to earn it' (Rose et al. 2003, p. 62).

Kincentric Indigenous cultures are, as Moreton-Robinson writes, 'constituted by our histories, our culturally embodied knowledges and life force that connect us to our respective lands, our creators, all living entities and our ancestors' (Moreton-Robinson 2017, p.71). Kinship relationships or knowledge are understood to be axiological expressions, or dynamic ethical systems which are governed by a spiritual reverence for the land (Harrison 2009). 'Indigenous knowledges take account of and care for the multiplicity of relations that exist between the elements of creation, all of which are endowed with life and agency' (Blaser et al. 2011, p. 9). Put simply, Indigenous kinship systems are not merely descriptions of relationships, but also describe ways of living well, laws for strengthening human and more-than-human life, and restoring and nurturing SEWB.

Many forms of Indigenous governance-or Indigenous axiologies, ethics—are founded on a complex kinship with the land. The complexities of Indigenous kinships systems across the earth are beyond the scope of this paper, but it is worth noting that the emerging scholarship in this area repeatedly calls attention to the ways in which strong kinship with the land is understood to a source of cultural healing. For example, the Maori peoples use the term whakapapa to describe a genealogical system which links all life, human and more-than-human, through a healing kinship with the land (Graham 2005). The world view of whakapapa acknowledges that land is kin and land has kinship rights (Kothari and Bajpai 2017). For many Indigenous peoples, such kinship relations are a primary source of health. The Yukon First Nation Elders 'politics of kinship' recognize water as a 'relative, teacher, medicine, and healer' (Wilson and Inkster 2018). Describing the kinship system of the Raramuri peoples whose homelands is a region they call Gawi Wachi (Place of Healing) in eastern Sierra Madres of Chhuahua in Mexico, Salmon writes of iwigara, or the web of life: iwi means breath or soul, while 'iwigara' means the web of life, the kinship of the web of life (Salmon 2000, p. 1328).

With the awareness that one's breath is shared by all surrounding life, that one's emergence into the world was possibly caused by some of the life-forms around ones environment, and that one is responsible for its mutual survival, it becomes apparent that it is related to you; that it shares a kinship with you and with all humans, as does a family or tribe. A reciprocal relationship has been fostered with the realisation that humans affect nature and nature 
affects humans. This awareness influences indigenous interactions with the environment. It is these interactions, those cultural practices of living with a place that are manifestations of kincentric ecology' (Salmon 2000, p. 1331-32)

Indigenous relationality is recognized as the life force, and that which supports and nourishes life. Other culturally specific iterations of this life-affirming Indigenous kinship with the land can be found in the Cree kinship law of awawanenitakik which recognizes the land as 'a teacher of law and governance to whom we are accountable. [ ... ] awanenitakik travels with us as it guides the way we approach relationships with other human and non-human kin beyond our muskeg lands' (Daigle 2016, p. 8). In this context, Cree self-determination is not controlled by western laws, but involves the everyday Indigenous practice of kinship, awanenitakik, and the practice of cultural ceremonies which build relationships between non-human and human kin. Moreover, for the Cree and many other Indigenous peoples, the cultural practice and experience of kinship is the spiritual foundation' of Indigenous 'forms of governance' (Daigle 2016, p. 9). These forms of governance are based on respect for and responsibility to a land which radiates consciousness and agency. The Yanyuwa people of North Australia, for example, practice a kinship with the land which is their communities 'epistemology, ontology and axiology' (Kearney 2017, p. 9).

The complex Aboriginal and Torres Strait Islander concept of kinship, then, can be understood as cultural ways of knowing, being and doing, which also describe paths to strengthening social and emotional wellbeing. Across Australia, there are numerous words for such kinship systems, which are all culturally distinct yet share a common spiritual and political kinship with the land. Within the country now called Australia, kinship with the land is both the foundation and expression of being and culture. This form of 'kincentric ecology' (Salmon 2000) recognizes the spiritual agency of the land, or Country.

In Aboriginal english, the word 'country' is both a common noun and a proper noun. People talk about country in the same way they would talk about a person: they speak to country, sing to country, visit country, worry about country, grieve for country and long for country. People say that country knows, smell, hears, takes notice, takes care, and feels sorry or happy. Country is a living entity with a yesterday, a today and a tomorrow, with consciousness, action and a will towards life. Because of this richness, country is home and peace, nourishment for the body, mind, spirit; heart's ease ...

Country is multi-dimensional-it consists of people, animals, plants, Dreamings, and underground, earth, soils minerals and waters, surface water, air. There is sea country and land country; in some areas people talk about sky country. Country has origins and a future. It exists both in time and through time. As I use the term here I refer to areas of land and/or sea including subsurface and sky above, in so far as Aboriginal people identify all these components as being part of country'. (Rose 1996, pp. 7-8)

An important subtlety here is that kinship with Country is recognized as an expression of Country-the Country is kinship and Country teaches kinship. As Yuin Elder Guboo Ted Thomas put it, 'the mountain teaches the dreaming' (Kindersley 2018, p. 307). An understanding of this form of kinship requires thinking through this intimate, sacred, dynamic and complex connection with Country as an expression of Country itself, a form of becoming-Country or building 'people as country themselves' (Preaud 2009, p. 9).

One of the most comprehensive investigations into Australian kinships systems, Indigenous Kinship with the Natural World in New South Wales (Rose et al. 2003), demonstrates the complexities of Indigenous genealogy. As the authors of this study point out, western research into kinship systems in Australia have tended to marginalize and erase the role of women in sustaining and guiding the cultural transmission of kinship and the knowledge systems, and forms of governance, kinship relations communicate. One purpose of this article is to highlight the role of women in creating and maintaining kinship. 


\section{Kinship and Women's Law}

Prior to colonization, Aboriginal and Torres Strait Islander women had a strong and respected place within their cultures. The land was often recognized as mother, and women the custodians. Women's law, or Grandmother law, was pivotal to the harmonious governance of a land mass twice the size of Europe. As Watson writes, since the patriarchal invasion of Indigenous women's land, 'women's law risks erasure':

In the old days, the law stories of women lived in the land and held a place in the lives of the peoples they belonged to, but now the law-full woman is diminished ... Our stories of women are often sacred and secret, and there is a reason for this, for we can see the danger of women's stories becoming subverted and becoming something else when they are retold within patriarchal frameworks'. (Watson 2014, p. 52)

Women's law has indeed been subjected to erasure and patriarchal appropriation, although female anthropologists with an underlying feminist approach have challenged the previous depictions of women's knowledges and roles directly against male knowledges and power. For example, Kaberry's significant work, Aboriginal Women: Sacred and Profane (Kaberry 1939), has remained largely ignored until recent times as it challenged the commonly held perceptions of the role of Aboriginal women. Other texts such as the work of Catherine Berndt $(1965,1981,1986,1989)$, Women's Role in Aboriginal Society (Gale 1970) edited by Fay Gale, Tiwi Wives: A study of the women of Melville Island, North Australia (Goodale 1974) by Jane Goodale, Daughters of the Dreaming (Bell 1983) by Diane Bell, and Women's Rites And Sites: Aboriginal Women's Cultural Knowledge (Brock 1989) edited by Peggy Brock, have challenged the previous depictions and widely propagated views of Aboriginal women as slaves and drudges.

Diane Bell's work Daughters of the Dreaming (1983) was a groundbreaking and challenging text that placed Aboriginal women as equal to, and in some instances, appearing more powerful then Aboriginal men. The study of the Warrabri of central Australia from the women's perception of themselves and their roles within a feminist standpoint and analysis showed that women had religious responsibilities, ceremonies and sacred artefacts for the purpose of upholding the Dreaming. The women's self-perceptions were that they were 'bosses for themselves', and this was manifested in economic, social and ritual spheres.

Warrabri women had direct access to the Jukurrpa, the Law of the Dreamtime, and rights and responsibilities to the land. Women had closed gender ceremonies called Yuwulyu, where elderly ritual women presided and summoned other women, young, old, single, married, widowed and divorced to participate and help in the preparation and performance of the ceremony. Women also had a women's camp, the Jilmi, which was an area for widowed and single women. Within the Jilmi was an area of authority, the ring place, where serious matters, rituals and ceremonies were undertaken. There was also a 'keeping place' where sacred objects were secluded and stored. Men avoided the ring place and were afraid of some women's business such as Yilpinji ceremonies. Bell concluded:

Here was a confident group of women secure in the value of their own knowledge and worth, whose self-perceptions begin within their own ritual and social worlds and extended to the wider society. In the attitudes of men and women, it was obvious that the body of knowledge and beliefs about the ancestral travels was shared jointly as a sacred trust, but it was also obvious that men and women had distinct and separate responsibilities for the ritual maintenance of this heritage'. (Bell 1983, p. 34)

Bell claimed that the differences in her findings were due to situating and locating herself almost exclusively in the women's camp, the Jilmi, and being given access to women's business. Coming from a woman's standpoint gave a different perspective: '[n]ew understandings emerge when women are allowed to speak' (Bell 1983). Bell's research directly challenged the previous depictions of Aboriginal people that positioned women as having little or less power than men, and led to considerable 
debate. In the epilogue of the reprinted Daughters of the Dreaming (Bell 1983), Bell concluded that male perspectives of the field continue to be used despite work like hers.

Like Kaberry (1939) and Berndt and Berndt (1988), Bell challenged the perception that Aboriginal women were second-class citizens:

Their lives were not ones of drudgery, deprivation, humiliation and exploitation, because of their lack of penis and attendant phallic culture, nor was their self-image and identity bound up solely with their child rearing functions. Instead I found the women to be extremely serious in the upholding, observance and transmission of their religious heritage. Religion permeated every aspect of their lives-lives which are nonetheless full of good humour and a sense of fun'. (Bell 1983, p. 231)

Aboriginal women's lives, like that of Aboriginal men, commenced in the spiritual domain, was lived with deep connections to the life forces of all living beings in the earth, sky and waters and finally the life of an Aboriginal woman ended in a return to the spiritual world.

Bells' book Daughters of the Dreaming (Bell 1983) broke new ground insofar as it was the first feminist challenge to the patriarchal bias which informed mainstream expert accounts of women's power. Bell discusses yilpinji or the invocation of women's power in what has previously been described (somewhat salaciously and redundantly by patriarchal ethnologists) as 'love rituals':

'Yilpinji is achieved through a creative integration of myth, song, gesture and design against a backdrop of country. The circle, the quintessential female symbol, finds expression in the body designs, the rolling hand gestures and patterns traced out by the dancing feet. Certain yilpinji and health/curing designs are the same, because, as Kaytej women recognise, love, health, and sexual satisfaction are intertwined at the personal and community level'. (Bell 1983)

The female symbol of the circle also connects to the holistic epistemology, ontology and axiology of Indigenous kinship systems which are also known as the Grandmother or Granny Laws. The following section explores this in more depth.

\section{Grandmother's Law and Birthing on Country: Kinship and Social and Emotional Wellbeing}

As discussed above, traditional Australian Indigenous cultures had numerous laws governing the responsibilities of men and women to families, communities, culture and Country which are often now referred to as men's business and women's business, much of which is sacred and remains secret. One of the more powerful laws is Grandmothers' Law which is a holistic Law governing a whole way of living, an axiology of wellbeing, guiding kinship connections and the spiritual and cultural foundations of families, in particular the sacred women's business of pregnancy, birth, and child-care (Ward 2018; Ramsamy 2014; Wall 2010, 2017). In many ways, the SEWB of women, children, indeed the flourishing of communities and the future of those communities was an expression of these Grandmother Laws. Colleen Wall (2017) explains some of the cultural complexities of this Law in the following way:

Grandmother's Law is one half of Land Law where men and women hold balanced positions with reciprocal responsibilities for maintaining societal equilibrium.

Grandfathers look outwardly, protecting the camp. Grandmothers look inwardly, nurturing new generations of respectful, responsible and resilient youth who will 'look after country' to benefit both land and people.

Reinstating this teaching system within our respective lands develops continuous knowledge of children's 'place' in society and responsibilities as parents.

The Grandmothers' Law underpins the Birthing on Country movement (Kildea et al. 2018). The word and concept 'borning' is also used as a way of describing the culturally specific process 
of caring for women through the birth process which is an integral part of Indigenous cultures in Australia and which has been practiced for many thousands of years prior to colonization (Carter et al. 1987). An important part of the movement of Indigenous self-determination within the comprehensive primary health care section, Birthing on Country restores women's kinship connections to Country with the guidance of women Elders and healers, and affirms the spiritual and cultural empowerment of the birthing process. This cultural practice is defended and supported by the Indigenous women's group NAICC: National Voice for Our Children, a powerful, community-controlled organization dedicated to protecting children, young people, and families and strengthening self-determination through cultural identity (SNAICC 2019).

Birthing on Country can be understood as a form of reproductive justice (Dudgeon and Bray 2019) and pivotal to closing the substantial health gap between Indigenous and non-Indigenous women in Australia, for numerous studies have found that Birthing on Country is a culturally secure practice which results in increased SEWB for women and children (Coffin 2007, 2018; Kildea et al. 2018). According to the 2016 position statement of Birthing on Country, such models of care can be described as maternity services that are designed, developed, delivered and evaluated for and with Aboriginal and Torres Strait Islander women that encompass some (or all) of the following:

- they are community based and governed,

- provide for the inclusion of traditional practices,

- involve connections with land and country,

- incorporate a holistic definition of health,

- value Aboriginal and/or Torres Strait Islander as well as other ways of knowing and learning, and

- encompass risk assessment and service delivery and are culturally competent' (Birthing on Country Position Statement 2016, p. 3).

Kinship connections, with, for example, land and country, are central to this holistic cultural practice and to the support of SEWB.

One such organization which supports this cultural practice is Alukura, a women's congress which began in 1987 (Carter et al. 1987) after several hundred women in Central Australia from 60 communities and representing 11 different languages came together to form a women's only health service. Alukura cares for women 'under the strong cultural guidance of grandmother's law' (Central Australian Aboriginal Congress CAAC). There is also the Birthing on Noongar Boodjar a Cultural Security and Aboriginal Birthing Women Project which after five years of evidence gathering has recommended culturally secure maternity services pathway for Aboriginal women (Birthing on Noongar Boodjar Cultural Security \& Aboriginal Birthing Women). This project is under the guidance of the Ngangk Yira research center in Western Australia which is focused on improving SEWB and social equity. Ngangk Yira means the rising of the life-giving mother sun (Ngangk Yira Research Centre 2019).

The sun, as giver, protector, and renewer of life, is also at the center of the Aboriginal flag. As Watson writes

The Sun Woman illuminates the future and the future is a return to the beginnings as though we have never left them. Our songs and stories gave us knowledge for survival, to live a good life in harmony with all things. The song law passed from one generation to the next and was taken on by each generation as an obligation and commitment to the spirit ancestors. The original agreements entered into are still alive, as are the obligations to honour them. (Watson 2016, p. 163)

As has been reiterated throughout this article, such obligations are part of kinship laws which support the flourishing of SEWB, and are expressed through Grandmothers' Law. 


\section{Conclusions}

To talk of Indigenous genealogy, then, is to talk about kinship with all forms of life, Indigenous governance and therapeutic knowledge systems. Most of all, however, it is to talk about reciprocal connections with the land, or Country which express reverence and above all, love. As the Tanganekald and Meintangk lawyer and philosopher Irene Watson writes about Raw Law, kinship with the land: 'The overriding principle we live by is a love of the land, a relationship of custodianship between the land and nungas' (Watson 2016, p. 21). This law, continues Watson, 'lives in all things and emanates love' (Watson 2016, p. 12) and carries 'obligations and responsibilities, such as custodial obligations to ruie [homelands] that bind future generations' (Watson 2016, p. 14). Elder Tjilpi Randall uses the word Kanyini to describe the unconditional love which is based on Nguru, a sense of belonging to home and land, Walytja, a kinship with all life, Kurunpa, love, spirit, or soul and Tjuukurpa, the right way to live according to the law. In a filmed interview, Elder Randall talks about how his understanding of this knowledge system is 'Granny Law' and that this has been taught to him, and is about caring for Country, 'caring for my mother, caring for everything around me' [ ... ] caring with unconditional love ... with that responsibility' (Randall 2009). As the above discussion has highlighted, Grandmother Laws underpin the Birthing on Country movement which is an integral part of restoring both the SEWB of women and their communities. Grandmother Law, then, is one way of describing the complex system of ontological, epistemological and axiological relationships which compose women's dynamic cultural knowledge which cannot fully be translated into the western concept of kinship or genealogy.

Finally, it is worth listening to June Oscar who affirms the importance of women's strengths-based custodial kinship with the land as the source of wellbeing and environmental reproductive justice:

[C]ountry is where my people need to be able to draw positive emotions, meaning and purpose, self-esteem and resilience. The land provides what we call in the Bunuba language Ngarranggani. Ngarranggani lies at the heart of our culture; it is timeless, and it is all past, present and future. It is our dreaming, our creator, our kinship, morality and ethics. We are of the land, and to care for and protect the land is to nurture and safeguard our families and our future. This intimately entwined relationship of land, language and culture is common to Indigenous peoples across the world. Language is a vehicle to transmit the cultural strengths I've referred to, and to heal our communities and reconcile our nation. (Oscar 2017)

Author Contributions: All authors have equal contributions.

Funding: No funding to declare.

Conflicts of Interest: The authors declare no conflict of interest.

\section{References}

Bell, Diane. 1983. Daughters of the Dreaming. Minneapolis: University of Minnesota Press.

Berndt, Catherine Helen. 1965. Women and the 'Secret' Life. In Aboriginal Man in Australian Society. Edited by R. M. Brendt and C. H. Berndt. Sydney: Angus \& Robertson, pp. 238-82.

Berndt, Catherine Helen. 1981. Interpretations and 'facts' in Aboriginal Australia. In Woman the Gatherer. Edited by F. Dahlberg. New Haven: Yale University Press, pp. 153-203.

Berndt, Catherine Helen. 1986. Digging sticks and spears, or, the two sexed model. In Women's Role in Aboriginal Society; Edited by F. Gale. Canberra: Australian Institute of Aboriginal Studies, pp. 64-84.

Berndt, Catherine Helen. 1989. Retrospect, and prospect: Looking back over 50 years. In Women Rites and Sites: Aboriginal Women's Cultural Knowledge. Edited by P. Brock. Sydney: Allen \& Unwin, pp. 1-20.

Berndt, Ronald Murray, and Catherine H. Berndt. 1988. Australian Institute of Aboriginal and Torres Strait Islander Studies. Magic and Sorcery [Online] World of the First Australians: Aboriginal Traditional Life-Past and Present, 5th ed. Canberra: Aboriginal Studies Press, pp. 304-31. ISBN 0855751843. Available online: http://search.informit.com.au/documentSummary;dn=462674716525529;res=IELIND (accessed on 29 December 2015). 
Biddle, Nicholas. 2011. Physical and Mental Health. Measures of Indigenous Wellbeing and Their Determinants across the Life Course. CAEPR Lecture Series, Lecture 3; Canberra: Centre for Aboriginal Economic Policy Research, Australian National University, Available online: http://caepr.anu.edu.au/sites/default/files/page/2011/01/ Lecture03Paper.pdf (accessed on 25 April 2019).

Biddle, Nicholas, and Hannah Swee. 2012. The relationship between wellbeing and Indigenous land, language and culture in Australia. Australian Geographer 43: 215-32. [CrossRef]

Birthing on Country Position Statement. 2016. Available online: https://www.catsinam.org.au/static/uploads/ files/birthing-on-country-position-statement-endorsed-march-2016-wfaxpyhvmxrw.pdf (accessed on 25 April 2019).

Birthing on Noongar Boodjar (Cultural Security \& Aboriginal Birthing Women) Project Recommendations. 2018. Available online: https://www.catsinam.org.au/static/uploads/files/birthing-on-noongar-boodjar-projectrecommendations-final-wfgeigmidylu.pdf (accessed on 25 April 2019).

Blaser, Mario, Ravi De Costa, Deborah McGregor, and William D. Coleman, eds. 2011. 'Reconfiguring the web of life: Indigenous peoples, relationality, and globalization. In Indigenous Peoples and Autonomy: Insights for a Global Age. Vancouver: University of British Colombia Press, pp. 1-26.

Brock, Peggy, ed. 1989. Women, Rites and Sites: Aboriginal Women's Cultural Knowledge. Sydney: Allen \& Unwin.

Burgess, P. Christopher, Helen L. Berry, Wendy Gunthorpe, and Ross S. Bailie. 2008. Development and preliminary validation of the 'Caring for Country' questionnaire: Measurement of an Indigenous Australian health determinant. International Journal for Equity in Health 7: 26. [CrossRef] [PubMed]

Burgess, P. Christopher, Fay H. Johnston, Helen L. Berry, Joseph McDonnell, Dean Yibarbuk, Charlie Gunabarra, Albert Mileran, and Ross S. Bailie. 2009. Healthy country, healthy people: The relationship between Indigenous health status and caring for country. Medical Journal of Australia 190: 567-72. [PubMed]

Central Australian Aboriginal Congress (CAAC). 2017. Congress Alukura Celebrates 30 Years. September 24. Available online: https://www.caac.org.au/news-events/media-releases/2017/9/congress-alukura-celebrates30-years (accessed on 25 April 2019).

Carter, Betty, Eileen Hussen, Lana Abbott, Margaret Liddle, Mary Wighton, Maureen McCormack, Pip Duncan, and Pamela Nathan. 1987. Borning: Pmere Laltyeke Anwerne Ampe Mpwaretkeke, Congress Alukura by the Grandmother's Law. Australian Aboriginal Studies 2.

Coffin, Juli. 2007. Rising to the challenge in Aboriginal health by creating cultural security. Aboriginal and Islander Health Worker Journal 31: 22-24.

Coffin, Juli. 2018. Birthing on Noongar Boodjar with Cultural Security. Keynote address presented at the Birthing on Noongar Boodjar Symposium. Available online: https://www.telethonkids.org.au/our-research/earlyenvironment/developmental-origins-of-child-health/aboriginal-maternal-health-and-child-development/ the-cultural-security-of-aboriginal-mothers/ (accessed on 25 April 2019).

Country Needs People: Protecting Nature, Transforming Lives. 2018. Strong Women on Country: The Success of Women Caring for Country as Indigenous Ranges and on Indigenous Protected Areas. Available online: countryneedspeople.org.au (accessed on 25 April 2019).

Daigle, Michelle. 2016. Awawanenitakik: The spatial politics of recognition and relational geographies of Indigenous self-determination. The Canadian Geographer 60: 1-11. [CrossRef]

Dietsche, Elaine, Tanya Martin, Pamela Shackelton, Carmel Davies, Margaret McLeod, and Margaret Alston. 2011. Australian Aboriginal kinship: A means to enhance maternal well-being. Women and Birth: Journal of the Australian College of Midwives 24: 58-64. [CrossRef] [PubMed]

Dudgeon, Pat, and Abigail Bray. 2019. Reproductive justice and culturally safe approaches to sexual and reproductive health for Indigenous women and girls. In Routledge International Handbook of Women's Sexual and Reproductive Health. Edited by Ussher Jane, Joan Chrisler and Janette Perz. London: Routledge, in press.

Dudgeon, Pat, and Roz Walker. 2015. Decolonizing Australian psychology: Discourses, strategies, and practice. Journal of Social and Political Psychology 3: 276-97. [CrossRef]

Dudgeon, Pat, Bray Abiogai, Belinda D'Costa, and Roz Walker. 2017. De-colonising psychology: Validating social and emotional wellbeing. Australian Psychologist 52: 316-25. [CrossRef]

Elkin, Adolphus Pete. 1993. Aboriginal Men of High Degree: Initiation and Sorcery in the World's Oldest Tradition. Rochester: Inner Traditions/Bear \& Co.

Gale, Fay. 1970. Women's Role in Aboriginal Society; Canberra: Australian Institute of Aboriginal Studies. 
Goodale, Jane Carter. 1974. Tiwi Wives: A Study of the Women of Melville Island, North Australia. Washington, DC: University of Washinton Press.

Graham, James P. H. 2005. He apiti hono, he tatai hono: That which is joined remains an unbroken line-Using whakapapa (genealogy) as the basis for an Indigenous Research framework. Australian Journal of Indigenous Education 34: 86-95. [CrossRef]

Harrison, Max Dulumunmun. 2009. My People's Dreaming: An Aboriginal Elder Speaks on Life, Land, Spirit and Forgiveness. Warriewood: Finch Publishing.

Hayman-Reber, M. 2018. Removal of Djap Wurrung Trees an 'Act of Cultural Terrorism, 19th June, NITV News. Available online: https://www.sbs.com.au/nitv/nitv-news/article/2018/06/18/removal-sacred-djap-wurrungtrees-act-cultural-terrorism (accessed on 25 April 2019).

Hoover, Elizabeth. 2018. Environmental reproductive justice: Intersections in an American Indian community impact by environmental contamination. Environmental Sociology 4: 8-21. [CrossRef]

Kaberry, Phyllis. 1939. Aboriginal Woman: Sacred and Profane. London and England: Routledge \& Kegan Paul.

Kearney, Amanda. 2017. Violence in Place: Cultural and Environmental Wounding. Oxon and New York: Routledge.

Kildea, Sue, Sophie Hickey, Carmel Neson, Jody Currie, Adrian Carson, Maree Reynolds, Sue Kruske, Roianne West, Anton Clifford, and Machellee Kosiak. 2018. Birthing on country (in our community): A case study of engaging stakeholders and developing a best-practice Indigenous maternity service in an urban setting. Australian Health Review 42: 230-38. [CrossRef] [PubMed]

Kindersley, D. 2018. The Mythology Book: Big Ideas Simply Explained. London and New York: Random House.

Kothari, Ashish, and Shrishtee Bajpai. 2017. Rivers and Human Rights: We are the River, the River is Us? Engage: Economic and Political Weekly. Available online: http://www.epw.in/engage/artile/we-are-the-river-river-us (accessed on 25 April 2019).

Lowell, Anne, Sue Kildea, Marlene Liddle, Barbara Cox, and Barbara Paterson. 2015. Supporting Aboriginal knowledge and practice in health care: Lessons from a qualitative evaluation of the Strong Women, Strong Babies, Strong Culture Program. BMC Pregnancy and Childbirth 15: 19. [CrossRef] [PubMed]

Moreton-Robinson, Aileen. 2017. Relationality: A key presupposition of an indigenous social research paradigm. In Sources and Methods in Indigenous Studies. Edited by Andersen Chris and O'Brien Jeani. New York: Routledge, pp. 69-77.

Neijie, Bill. 1989. Story about Feeling. Broome: Magabala Books.

Ngangk Yira Research Centre. 2019. Available online: https://www.murdoch.edu.au/research/institutes-centres/ health-futures-institute/ngangk-yira-aboriginal-health-research-centre (accessed on 25 April 2019).

Oscar, June. 2017. Resilience and Reconstruction: Women's Agency in Rebuilding Strong Communities. Griffith Review. Available online: https://griffithreview.com/articles/resilience-reconstruction-womens-agencystrong-communities-june-oscar/ (accessed on 25 April 2019).

Oscar, June. 2018. 'Because of Her, We Can' National Aboriginal and Torres Strait Islander Women's Conference. Thursday 12th July 2018. Australian Human Rights Commission. Available online: https://www.humanrights.gov.au/news/speeches/because-her-we-can-national-aboriginal-andtorres-strait-islander-women-s-conference (accessed on 25 April 2019).

Powell, Dana E., and Andrew Curley. 2008. K'e, Hozho, and non-governmental politics on the Navajo Nation: ontologies of difference manifest in Environmental Activism. Anthropological Quarterly 81: 17-58.

Preaud, Martin. 2009. Country, Law and Culture (Anthropology of Indigenous Networks from the Kimberley). Ph.D. thesis, James Cook University, Douglas, Australia.

Ramsamy, Nicole. 2014. Indigenous birthing in remote locations: Grandmothers' Law and government medicine. In Yatdjuligin: Aboriginal and Torres Strait Islander Nursing \& Midwifery Care. Edited by Odette Best and B. Fredericks. Melbourne: Cambridge University Press, pp. 102-19.

Randall, Tjilpi. 2009. The Land Own Us. Available online: https://www.youtube.com/watch?v=w0sWIVR1hXw (accessed on 25 April 2019).

Reo, Nicholas J., and Laura A. Ogden. 2018. Anishnaabe Aki: An indigenous perspective on the global threat of invasive species. Sustainability Science 13: 1443-52. [CrossRef]

Rose, Deborah Bird. 1996. Nourishing Terrains: Australian Aboriginal Voices of Landscape and Wilderness; Canberra: Australian Heritage Commission.

Rose, Deborah, Diana James, and Christine Watson. 2003. Indigenous Kinship with the Natural World in New South Wales; Huntsville: NSW National Parks and Wildlife Service. 
Salmon, Enrique. 2000. Kincentric ecology: Indigenous perceptions of the human-nature relationship. Ecologcal Applications 10: 1327-32.

SNAICC. 2019. SNAICC: National Voice for Our Children. Available online: https://www.snaicc.org.au (accessed on 25 April 2019).

Wall, Colleen. 2010. Law and Story-Strings. Queensland Historical Atlas: Histories, Cultures, Landscapes. Available online: https://www.qhatlas.com.au/content/law-and-story-strings (accessed on 25 April 2019).

Wall, Colleen. 2017. Aboriginal Grandmothers Law. Aboriginal Institute of Aboriginal and Torres Strait Islander Studies. Available online: https://aiatsis.gov.au/publications/presentations/aboriginal-grandmothers-law (accessed on 31 August 2018).

Ward, Nura Nungalka. 2018. Grandmothers' Law. Broome: Magabala Books.

Watson, Irene. 1998. Naked peoples: Rules and regulations. Law Text Culture 4: 1-17.

Watson, Irene. 2008. De-Colonising the Space: Dreaming Back to Country. Heartsick for Country. pp. 82-100. Available online: https://ssrn.com/abstract=2476804 (accessed on 25 April 2019).

Watson, Irene. 2014. First Nations Stories, Grandmother's Law: Too Many Stories too Tell. pp. 46-53. Available online: https://ssrn.com/abstract=2571143orhttp://dx.doi.org/10.2139/ssrn.2571143 (accessed on 25 April 2019).

Watson, Irene. 2016. Raw Law: Aboriginal Peoples, Colonialism and International Law. New York: Routledge.

Wilson, Nicole J., and Jody Inkster. 2018. Respecting water: Indigenous water governance, ontologies, and the politics of kinship. Environment and Planning E: Nature and Space 1: 516-38. [CrossRef]

Wooltorton, Sandra, Len Collard, and Pierre Horwitz. 2017. The land still speaks: Ni, Katitj! PAN: Philosophy, Activism, Nature 13: 57-67.

(C) 2019 by the authors. Licensee MDPI, Basel, Switzerland. This article is an open access article distributed under the terms and conditions of the Creative Commons Attribution (CC BY) license (http://creativecommons.org/licenses/by/4.0/). 